\section{Impact of universal childhood vaccination against hepatitis $B$ in Ghana: A pilot study}

\author{
Oheneba C.K. Hagan, ${ }^{1}$ Paul Nsiah, ${ }^{2}$ \\ Dorcas Obiri-Yeboah, ${ }^{3}$ Felix Yirdong, ${ }^{4}$ \\ Isaac Annan, ${ }^{5}$ Sebastian Eliason, ${ }^{6}$ \\ Samuel V. Nuvor ${ }^{3}$ \\ ${ }^{1}$ University of Cape Coast School of \\ Medical Sciences, Department of \\ Medical Biochemistry, Cape Coast \\ Ghana; ${ }^{2}$ University of Cape Coast \\ School of Medical Sciences, Department \\ of Chemical Pathology, Cape Coast \\ Ghana; ${ }^{3}$ University of Cape Coast \\ School of Medical Sciences, Department \\ of Microbiology and Immunology, Cape \\ Coast Ghana; ${ }^{4}$ University of Cape Coast \\ School of Medical Sciences, Department \\ of Psychological Medicine and Mental \\ Health, Cape Coast Ghana; ${ }^{5}$ Howard \\ Community College, Maryland, USA; \\ ${ }^{6}$ University of Cape Coast School of \\ Medical Sciences, Department of \\ Community Medicine, Cape Coast, \\ Ghana
}

\begin{abstract}
Hepatitis B virus (HBV) infection is of public health importance worldwide. Vaccination against the infection, especially in early childhood has significantly reduced the public health impact. This pilot study was undertaken in Cape Coast Metropolitan area to assess the impact of the introduction of HBV vaccination in children. A cross-sectional multi-stage cluster sampling of 501 pupils from 30 public and private primary and junior high schools within the Cape Coast metropolis. A questionnaire covering basic demographic details and immunisation history were administered to the participants after consent and assent had been sought. Hepatitis B serological test for $\mathrm{HBsAg}$, $\mathrm{HBcAb}$, $\mathrm{HBsAb}, \mathrm{HBeAg}$ and HbeAb was undertaken using Hepatitis B test kit and capillary blood from the participants. The general prevalence of $\mathrm{HBcAb}, \mathrm{HBsAg}$ and $\mathrm{HBsAb}$ was found to be 3.6, 2.6 and $19.8 \%$ respectively. The prevalence of $\mathrm{HBcAb}$ was 2.6 and $6.1 \%$ among pupils delivered after and before the vaccine programme introduction respectively. Introduction of the vaccination programme in Ghana has had a positive impact on the $\mathrm{HBV}$ infection in Ghana
\end{abstract}

Correspondence: Oheneba Charles Kofi Hagan, Department of Medical Biochemistry, University of Cape Coast School of Medical Sciences, Cape Coast, Ghana.

Tel.: +233243311177.

E-mail: ock.hagan@uccsms.edu.gh

Samuel V. Nuvor, Department of Microbiology and Immunology, University of Cape Coast School of Medical Sciences, Cape Coast Ghana. Tel.: +233205853850. E-mail: s.v.nuvor@uccsms.edu.gh

Key words: Hepatitis B; Ghana; vaccination; children.

Acknowledgements: we would like to thank Mr Isaac Otchere and Mr Wisdom Akoto who were instrumental in the fieldwork of th study. We would also want to show appreciation to the Cape Coast Metropolitan Education Directorate and th institutional heads of all participating schools for granting us the permission to undertake the study in the schools

Funding: the study was conducted with a grant from Ghana-Michigan Collaborative Research Funding Program.

Contributions: the authors contributed equally.

Received for publication: 8 June 2017.

Accepted for publication: 10 July 2018

from infection, however, the elderly and the immuno- compromised individuals fair slightly worse. $^{6}$ The World Health Assembly in 1992 adopted the resolution recommending the introduction of hepatitis $B$ vaccination into national immunisation programmes. ${ }^{7}$ The World Health Organization (WHO) subsequently recommended the adoption of HBV vaccination into the immunisation programmes of all member states by 1997.8 In 2008, a Strategic Advisory Group of Experts on Immunization recommended the setting up of goals for the control of HBV according to each countries epidemiological state. ${ }^{9}$

Population-based HBsAg serological surveys was recommended as one of the tools for monitoring the impact of the vaccination programmes on Hepatitis B in high and moderate endemicity regions. ${ }^{10}$ Ghana adopted the universal childhood vaccination against Hepatitis B (UCVAHB) as part of the expanded immunisation programme in 2002. However, more than a decade after the introduction, no Hepatitis B sero- epidemiological survey has been undertaken in the target group to determine the effectiveness of the programme. This pilot study was therefore undertaken to determine the impact of the UCVAHB by employing the WHO manual for HBV vaccination impact analysis. ${ }^{10}$ This pilot study was therefore undertaken in primary and junior high schools in the Cape Coast Metropolitan area, a coastal city in southern Ghana with greater than $90 \%$ school attendance rate. ${ }^{11}$
This work is licensed under a Creative Commons Attribution NonCommercial 4.0 License (CC BY-NC 4.0).

(C) Copyright O.C.K. Hagan et al., 2018

Licensee PAGEPress, Italy

Journal of Public Health in Africa 2018; 9:721

doi:10.4081/jphia.2018.721

\section{Materials and Methods}

\section{Study design}

The study was conducted using a crosssectional multi-stage cluster sampling method.

Schools in the Cape Coast Metropolitan area were initially clustered into public primary, private primary, public junior high and private junior high. Allocation of clusters to each group was undertaken according to the total population of pupils in each group. A total of 30 clusters were chosen with $15,7,7$ and 1 clusters allocated to public primary, private primary, public junior high and private junior high respectively. Schools were then chosen randomly using a web-based random number generator tool. ${ }^{12}$ Classes from which the pupils were to be sampled from were chosen according to a predetermined order. Twenty pupils were then chosen randomly from each class 
using the class register and the random number generator.

The study was approved by the University of Cape Coast Institutional Review Board (UCCIRB/CHAS/2015/20), Ghana Education Service through the Cape Coast Metropolitan Education Office and the proprietors of the private schools.

\section{Study area}

Cape Coast Metropolitan is the capital of Central Region of Ghana; it is bounded on the south by the Gulf of Guinea, to the west by Komenda Edina Eguafo Abrem Municipality, to the east by Abura Asebu Kwamankese District, to the north by Twifo-Heman Lower-Denkyira District and to the south by the Atlantic Ocean. According to the 2010 Ghana Population and Housing Census, Cape Coast Metropolitan had a population of 169,894 with $28 \%$ of them being under 14 years of age. ${ }^{13}$

In 2012/13 the metropolis had a total of 110 primary schools out of which 45 were private and 92 junior high schools of which 32 were private. Enrolment in primary school was 25610 with 8,643 in private schools; in JHS the total enrolment was $10,921,28 \%$ of which are in private institutions. ${ }^{11}$

\section{Study population}

A total of 29 out of the 30 schools agreed to be part of the study, and consents were sought from the parents/guardians of the pupils chosen. Five hundred and three parents/guardians consented for their wards to be part of the study, however, 2 pupils declined to be part of the study and therefore were not included in the study
Questionnaires covering basic demographic details, immunisation history and parental history of HBV vaccination or infection were administered to the participants.

Testing for HBV infection was undertaken using the Hepatitis B combo test kit (Gemc Technology Group, Zhengzhou, Henan, China) and the tests performed according to the manufacturer's instructions. Briefly, about $2.5 \mathrm{~mL}$ of capillary blood was taken from a finger prick. About 0.5 millilitres of the capillary blood each was spotted into wells assigned to HBsAg, HBsAb, HBeAg, HBeAb and $\mathrm{HBcAb}$ and a buffer solution applied immediately. Readings were done after 15 minutes but not more than to 24 hours after the test.

\section{Results}

A total of 501 pupils were enrolled into the study, the mean age was $11.13 \pm 2.90$ years ranging between 5 to 21 years with a median age of 11 years. There were a total of 282 females and 219 males. The pupils were categorised into those delivered before and after the introduction of the UCVAHB according to their date of birth as at $20^{\text {th }}$ September 2015. The proportions were $77 \%$ and $23 \%$ respectively. The majority of enrollees were of Akan (80.6\%) ethnicity, followed by Ewes (8\%), Hausa (3.6\%) and other groups. One pupil each had parents originally from Nigeria and Niger but delivered in Ghana. The majority of the respondents were of the Christian faith $(82.4 \%)$ with the remainder being of the Islamic faith. About $97 \%$ of the respondents resided within the Cape Coast metropolis with the rest residing in the surrounding districts.

\section{Serological results}

Eighteen (3.6\%) out of the 501 participants, tested positive for $\mathrm{HBcAb}$. Overall, the prevalence of the HBsAg was $2.6 \%$, HBsAb was $19.8 \%$, HBeAg was $1 \%$ and $\mathrm{HBeAb}$ was $1.2 \%$. For the participants who tested positive for $\mathrm{HBcAb}, 13$ (72.2\%) tested positive for $\mathrm{HBsAg}, 6$ (33.3\%) tested positive for HBsAb, 5 (27.8\%) tested positive for $\mathrm{HBeAg}$ and 6 $(33.3 \%)$ tested positive for $\mathrm{HBeAb}$.

The prevalence of all the makers of HBV infection among pupils delivered before and after the introduction of the UCVAHB is represented in Figure 1. The prevalence of $\mathrm{HBcAb}$ was higher in children delivered before the introduction of the UCVAHB in Ghana compared with children delivered after the introduction. However, the prevalence of HBsAg was equal among the age groups. Of the 99 children who tested positive for $\mathrm{HBsAb}$, $17(17.2 \%)$ were delivered before the vaccine programme introduction and 82 $(82.8 \%)$ delivered after. Three children from each group tested positive both for $\mathrm{HBsAb}$ and $\mathrm{HBcAb}$ and 1 (delivered after) tested positive for $\mathrm{HBcAb}, \mathrm{HBsAg}$ and $\mathrm{HBsAb}$.

The proportion of $\mathrm{HBcAb}, \mathrm{HBsAg}$ and $\mathrm{HBs} \mathrm{b}$ among different categories of the participants with the p-value of the test of independence using Pearson's chi-square or Fisher's exact test is represented in Table 1. The test of independence were mostly insignificant at $\mathrm{P}$-value $<0.05$ except $\mathrm{HBcAb}$ and religion (P-value $=0.016)$ and HBsAg and ethnicity $(\mathrm{P}-\mathrm{value}=0.0005)$.

Vaccination records were available for

Table 1. Table showing the proportions of HBcAb, HBsAg and HBsAb among categories of pupils.

\begin{tabular}{|c|c|c|c|c|c|c|c|}
\hline $\begin{array}{l}\text { Category } \\
(\mathrm{N}=501)\end{array}$ & $\begin{array}{l}\text { Subcategory } \\
\text { (n) }\end{array}$ & $\begin{array}{l}\text { Proportion positive } \\
\text { for } \mathrm{HBcAb}(\%, \mathrm{CI})\end{array}$ & P-value & $\begin{array}{l}\text { Proportion positive } \\
\text { for HBsAg }(\%, \mathrm{CI})\end{array}$ & P-value & $\begin{array}{l}\text { Proportion positive } \\
\text { for } \mathrm{HBsAb}(\%)\end{array}$ & P-value \\
\hline Gender & Female (282) & $9(3.2,1.6-5.7)$ & Male (219) & $5(1.8,0.7-3.9)$ & 0.58 & $\begin{array}{c}8(3.7,1.7-6.8) \\
62(22.0,17.4-27.1)\end{array}$ & 0.91 \\
\hline Age category (years) & $\begin{array}{l}>13(114) \\
<13(387)\end{array}$ & $\begin{array}{l}7(6.1,2.7-11.8) \\
11(2.8,1.5-4.9)\end{array}$ & $0.048^{* \circ}$ & $\begin{array}{c}3(2.6,0.7-7.0) \\
10(2.6,1.3-4.6)\end{array}$ & $0.49^{\circ}$ & $\begin{array}{c}17(14.9,9.2-22.4) \\
82(21.2,17.3-25.5)\end{array}$ & $0.07^{\circ}$ \\
\hline Ethnicity & $\begin{array}{l}\text { Akan (404) } \\
\text { Hausa (18) } \\
\text { Ga (7) } \\
\text { Ewe (40) } \\
\text { Other (22) } \\
\text { Dagati (10) }\end{array}$ & $\begin{array}{c}12(3.0,1.6-5.0) \\
2(11.1,1.9-32.1) \\
0(0) \\
2(5.0,0.8-15.6) \\
2(9.1,1.6-26.9) \\
0(0)\end{array}$ & 0.29 & $\begin{array}{c}11(2.7,1.4-4.7) \\
1(5.6,0.3-24.5) \\
0(0) \\
1(2.5,0.1-11.7) \\
0(0) \\
0(0)\end{array}$ & 0.89 & $\begin{array}{c}68(16.8,13.4-20.7) \\
9(50,27.8-72.2) \\
2(28.6,5.1-67.0) \\
8(20.0,9.7-34.5) \\
10(45.5,25.9-66.1) \\
2(20.0,3.5-52.0)\end{array}$ & 0.0005 \\
\hline Residency & $\begin{array}{c}\text { Cape Coast (486) } \\
\text { Dutside Cape Coast (15) }\end{array}$ & $\begin{array}{l}17(3.5,2.1-5.4) \\
1(6.7,0.3-28.7)\end{array}$ & 0.52 & $\begin{array}{l}12(2.5,1.3-4.2) \\
1(6.7,0.3-28.7)\end{array}$ & 0.31 & $\begin{array}{c}95(19.5,16.2-23.3) \\
4(26.7,9.1-52.5)\end{array}$ & 0.50 \\
\hline Religion & $\begin{array}{l}\text { Christianity (413) } \\
\text { Islam (88) } \\
\end{array}$ & $\begin{array}{l}11(2.7,1.4-4.6) \\
7(8.0,3.5-15.1)\end{array}$ & $0.016^{*}$ & $\begin{array}{c}9(2.2,1.1-4.0) \\
4(4.5,1.5-10.6)\end{array}$ & 0.20 & $\begin{array}{l}76(18.4,14.9-22.4) \\
23(26.1,17.8-36.1)\end{array}$ & 0.098 \\
\hline
\end{tabular}

*P-value significant at or less than $0.05 \%$; ${ }^{\circ}$ one-tailed test of independence performed. 
$30(6 \%)$ of the respondents, 29 had completed the mandatory 3 schedules within the stipulated period and 1 did not complete the scheduled vaccination. None of these pupils tested positive for either $\mathrm{HBcAb}$ or HBsAg. However, only 9 of these pupils $(30 \%)$ with ages $5-13$ years, tested positive for $\mathrm{HbsAb}$ (Table 2).

\section{Discussion}

A systematic review of 30 Hepatitis B studies in Ghana has estimated the prevalence of Hepatitis B surface antigen (HBsAg) to be between 3.5 and $22.1 \%$, $86 \%$ of these studies reported a prevalence of $8 \%$ or above. ${ }^{14}$ The current study found the general prevalence of $\mathrm{HBsAg}$ to be $2.6 \%$ among children of all age groups. The prevalence among children delivered before or after the introduction of UCVAHB as part of the expanded immunisation programme in September 2002 was $2.6 \%$ for each group. However, the prevalence of Hepatitis B core antibody ( $\mathrm{HBcAb})$ a marker of previous or current infection was $2.8 \%$ in those delivered after the introduction of the vaccination programme compared with $6.1 \%$ in those delivered before. Most studies in Ghana have been biased towards the adult population, however, a study by Martinson et al found the prevalence of HBsAg and HBcAb among children in the central belt of Ghana to be about $15.8 \%$ and $54.8 \%$ respectively in $1996 .{ }^{15}$ Although this study was undertaken along the coastal belt of Ghana, the transmission dynamics would be similar and therefore the reduction in the prevalence of $\mathrm{HBV}$ infection over the period could be significant. The introduction of the UCVAHB has had a profound impact on disease burden in countries initially classified as high or moderate endemicity countries such as Taiwan, China, Laos, Malaysia in Asia; The Gambia and South Africa in Africa. ${ }^{16-21}$ The current study shows a significant difference between the prevalence of $\mathrm{HBcAb}$ in children delivered before and after the introduction of the vaccination programme. This could mean that the vaccination programme is reducing the chances of infection with HBV in Ghana as has been demonstrated in other countries.

The discrepancy between the HBsAg and $\mathrm{HBcAb}$ of pupils delivered after the vaccine programme introduction compared with those delivered afterwards could be attributed to sero-conversion of HBsAg as the children aged. Quantitative DNA measurements were not done to ascertain whether these children harboured occult blood infection or not.

Completion of the HBV vaccination schedule provides approximately 100\% protection against $\mathrm{HBV}$ infection for about 15 years, however, the HBsAg titres in serum begin to wane in the latter years of life. ${ }^{22}$ Vaccination records were available for only 30 out of the 501 pupils, and it was noted that none of these children tested positive for HBsAg or $\mathrm{HBcAb}$, however, the proportion of pupils positive for $\mathrm{HBsAb}$ was $30 \%(\mathrm{CI}=15.7-50.0 \%)$. The general HBsAb prevalence was $19.8 \%, 21.2 \%$ in children delivered after the vaccination programme and $14.9 \%$ in those delivered before although the difference is not significant. Although the difference in proportion was not significant, more children delivered after the vaccine introduction could be pro-

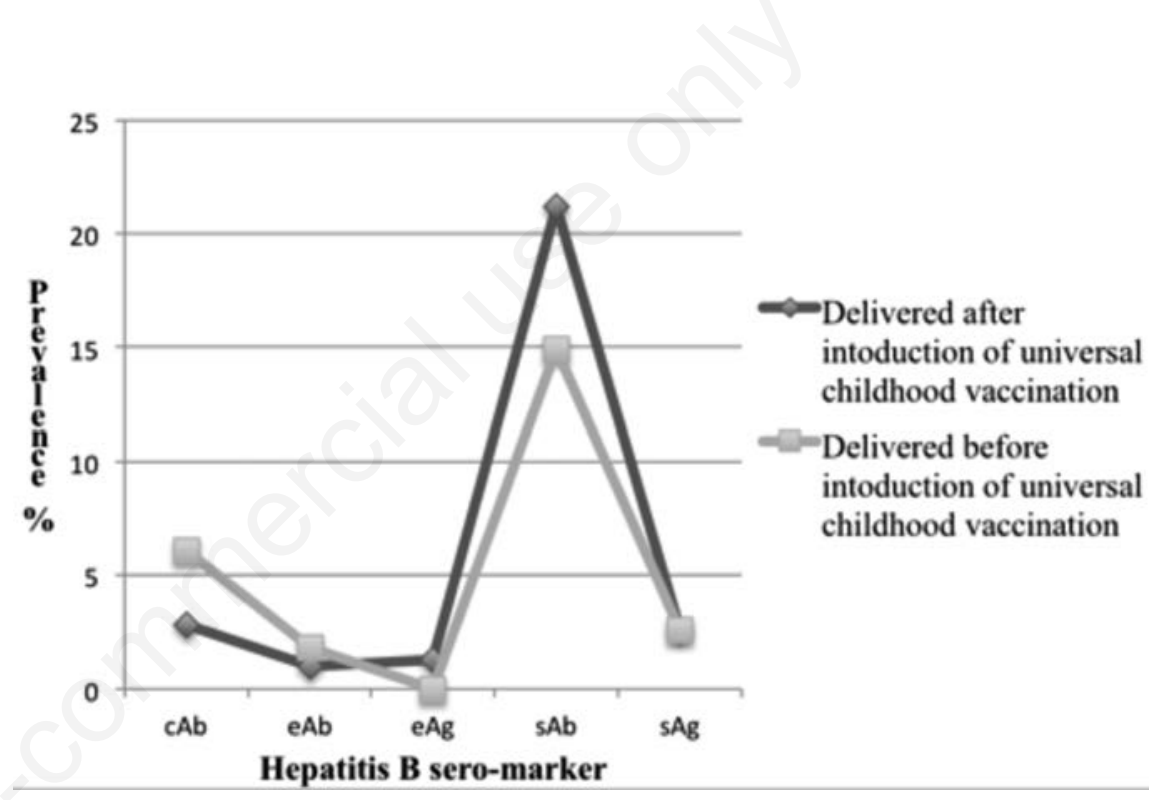

Figure 1. Line graph of proportions of hepatitis B seromarkers in children delivered before and after the introduction of the UCVAHB in Ghana.

Table 2. Table showing the odds ratio of categories of pupils to $\mathrm{HBcAb}, \mathrm{HBsAg}$ and $\mathrm{HBs} \mathrm{Ab}$ positivity.

\begin{tabular}{lccc} 
& HBCAg & HiBsAg & \\
Male (reference) & & Unadjusted OR (Cl=95\%) & 1 \\
Female & 1 & 1 & $1.38(0.88,2.18)$ \\
13 (reference) & $0.77(0.30,1.97)$ & $0.82(0.26,2.54)$ & 1 \\
13 & 1 & 1 & $0.65(0.37,1.15)$ \\
\hline Akan (reference) & $2.24(0.85,5.91)$ & $1.01(0.28,3.77)$ & 1 \\
Hausa & 1 & 1 & $4.94(1.89,12.90)$ \\
Ewe & $4.08(0.84,19.79)$ & $0.92(0.11,7.28)$ & $1.24(0.55,2.80)$ \\
Ga & $1.72(0.37,7.97)$ & 0 & $1.98(0.38,10.4)$ \\
Dagati & 0 & 0 & $1.24(0.26,5.95)$ \\
Others & 0 & 0 & $4.11(1.71,9.91)$ \\
Cape Coast (reference) & $3.27(0.68,15.59)$ & 1 & 1 \\
Outside Cape Coast & 1 & $2.82(0.34,23.23)$ & $1.50(0.47,4.80)$ \\
Christianity (reference) & $1.97(0.24,15.86)$ & 1 & 1 \\
Islam & 1 & $2.13(0.64,7.10)$ & $1.57(0.92,2.68)$ \\
\hline
\end{tabular}


tected from HBV infection.

Protective HBsAb serum levels have been found to wane gradually over time after the completion of the vaccination schedule with little or no breakthrough infection due to anamnestic response to reinfection. ${ }^{6,23}$ In a study in Turkey, it was found that about $87 \%$ of children had the protective level of serum HBsAb 5 years after vaccination schedule completion. ${ }^{24}$ In Saudi Arabia and Iran, a study of school children revealed a HBsAb prevalence of about $75 \%$ over the same period. ${ }^{25,26}$ The prevalence of about $20 \%$ in the present study is considerably lower than those from the aforementioned countries and therefore most children could be unprotected against HBV infection. Straimer et al., ${ }^{27}$ found that patients who had been previously vaccinated but with partners having high viraemic chronic HBV infection were of a greater chance of infection as the HBsAb protection wanes.

One of the impacts of vaccination against HBV in children is the selection of immune escape mutants resulting from breakthrough infection. ${ }^{28}$ In a study in Taiwan that followed up children vaccinated with HBV vaccine, as the HBsAb titres waned with age, there was an evidence of sero-conversion to $\mathrm{HBcAb}$, though without HBsAg positivity. ${ }^{29}$ There were 6 children who showed evidence of $\mathrm{HBcAb}$ sero-conversion in presence of HBsAg positivity, one of these pupils was positive for $\mathrm{HBsAg}$ a marker of chronic infection.

\section{Conclusions}

The prevalence of $\mathrm{HBsAg}$ and $\mathrm{HBcAb}$ among pupils were found to be lower than the national average especially pupils delivered after the introduction of UCVAHB in Ghana. The prevalence of HBsAb a marker of protection was higher in pupils delivered after UCVAHB introduction compared with pupils delivered before.

\section{References}

1. WHO. WHO | Guidelines for the prevention, care and treatment of persons with chronic hepatitis B infection. World Health Organization; 2015 [cited 2015 Aug 16]; Available from: http://www.who.int/hiv/pub/hepatitis/h epatitis-b-guidelines/en/

2. Trépo C, Chan HLY, Lok A. Hepatitis B virus infection. Lancet 2014;384:205363.
3. World Health Organization. WHO Hepatitis B [Internet]. World Health Organization; 2015 [cited 2015 Jul 10]. p. 1-5. Available from: http://www.who.int/mediacentre/factsheets/fs204/en/

4. Chu C-M, Liaw Y-F. Natural History of Hepatitis B Virus Infection. Hepatitis B Virus Hum Dis 2016;22:217-47.

5. Nelson NP, Easterbrook PJ, McMahon BJ. Epidemiology of Hepatitis B Virus Infection and Impact of Vaccination on Disease. Clin Liver Dis 2016;20:60728.

6. Zanetti AR, Van Damme P, Shouval D. The global impact of vaccination against hepatitis B: A historical overview. Vaccine 2008;26:6266-73.

7. WHO. SIXTY-THIRD WORLD HEALTH ASSEMBLY Viral Hepatitis Report By The Secretariat THE DISEASES AND BURDEN [Internet]. 2010 [cited 2017 Apr 21]. Available from: http://apps.who.int/gb /ebwha/pdf_files/WHA63/A63_15en.pdf

9. World Health Organisation. Weekly Epidemiological Record. 2009 [cited 2017 Apr 22];84(84):1-16. Available from: http://www.who.int/wer/2009/ wer8401_02.pdf

10. World Health Organisation. Documenting the impact of Hepatitis B immunization: best practices for conducting a serosurvey [Internet]. 2011 [cited 2014 Apr 23]. Available from: http://www.who.int/immunization/en/

11. Ghana Ministry of Education. Basic District Profile - 2012 / 2013 School Year Data [Internet]. 2013 [cited 2014 Sep 10]. Available from: http://www.moe.gov.gh/docs/Basic/201 2-2013/Basic District Profile.pdf

12. Urbaniak GC, Plous S. Research Randomizer [Internet]. 2014 [cited 2014 Oct 16]. Available from: https://www.randomizer.org

13. PHC. 2010 Population and housing census: Final results. Ghana Stat Serv Final results. 2012;11.

14. Ofori-Asenso R, Agyeman AA. Hepatitis B in Ghana: a systematic review \& meta-analysis of prevalence studies (1995-2015). BMC Infect Dis 2016;16:130.

15. Martinson FE, Weigle KA, Mushahwar IK, et al. Seroepidemiological survey of hepatitis $\mathrm{B}$ and $\mathrm{C}$ virus infections in Ghanaian children. J Med Virol 1996;48:278-83.

16. Chan CY, Lee SD, Lo KJ. Legend of hepatitis B vaccination: The Taiwan experience. J Gastroenterol Hepatol (Australia) 2004;121-6.

17. Viviani S, Jack A, Hall AJ, et al. Hepatitis B vaccination in infancy in The Gambia: Protection against carriage at 9 years of age. Vaccine 1999; 17:2946-50.

18. Xeuatvongsa A, Komada K, Kitamura T, et al. Chronic Hepatitis B Prevalence among Children and Mothers: Results from a Nationwide, [Internet]. PLoS 2014;9:e88829.

19. Liang X, Bi S, Yang W, et al. Evaluation of the Impact of Hepatitis B Vaccination among Children Born during 19922005 in China. Hepat B Vaccin Among Child@BULLET JID [Internet]. 2009 [cited 2017 Apr 17];200.

20. Ng KP, Saw TL, Baki A, et al. Impact of the Expanded Program of Immunization against hepatitis B infection in school children in Malaysia. Med Microbiol Immunol 2005;194:163-8.

21. Spearman CWN, Sonderup MW. Preventing hepatitis B and hepatocellular carcinoma in South Africa: The case for a birth-dose vaccine. South African Med J 2014;104:610.

22. Franco E, Bagnato B, Marino MG, et al. Hepatitis B: Epidemiology and prevention in developing countries. World J Hepatol 2012;4:74-80.

23. Su T-H, Chen P-J. Emerging hepatitis B virus infection in vaccinated populations: a rising concern? Emerg Microb Infect 2012;1:e27.

24. Kurugöl Z, Erensoy S, Akşit S, et al. Low-dose intradermal administration. Emerg Microbes Infect 2012;1:e27.

25. Jaber SM. Prevalence of anti-hepatitis $\mathrm{B}$ and anti-hepatitis A antibodies among school aged children in Western Saudi Arabia. Saudi Med J 2006;27:1515-22.

26. Shamsizadeh A, Makvandi M, Shoshtari G. Prevalence of anti hepatitis B surface antibody among children in Ahvaz, Iran, five years after vaccination. Jundishapur J Microbiol 2011;4: 49-54.

27. Stramer SL, Wend U, Candotti D, et al. Nucleic Acid Testing to Detect HBV Infection in Blood Donors. N Engl J Med 2011;364:236-47.

28. Coleman PF. Detecting hepatitis B surface antigen mutants. Emerg Infect Dis 2006;12:198-203.

29. Lin Y, Chang M, Ni Y, et al. Long-Term Immunogenicity and Efficacy of Universal Hepatitis B Virus Vaccination in Taiwan. J Infect Dis 2003;187:134-8. 